\title{
Prospective EFL Teachers` Beliefs about Language Learning and Gender Differences in a Higher Education Context
}

\author{
Heri Mudra ${ }^{1}$ \\ State College for Islamic Studies of Kerinci, Indonesia
}

\begin{abstract}
The purposes of this study were to find out the beliefs about English as a foreign language and statistical gender differences between male and female students at STAIN Kerinci. 100 male and female EFL students were involved in the survey employing Beliefs about Language Learning Inventory (BALLI) found by Horwitz (1987). Based on the analysis, there was no significant gender difference between the male and female students in terms of the beliefs about English as a foreign language, except for some items which showed statistically different in gender. The difference is on the item that states whether or not students who are good at maths could not understand English well. More female students believed in this statement, but only fewer male students did. Another difference between the gender is about whether or not they can ultimately understand English very well.
\end{abstract}

Submitted

06 January 2016

Revised

04 April 2016

Accepted

04 April 2016

Keywords:

Beliefs about Language

Learning (BALLS),

$E L T$,

EFL Learning,

\section{Suggested Citation:}

Mudra, Heri. (2016). Prospective EFL Teachers` Beliefs about Language Learning and Gender Differences in a Higher Education Context, International Journal of Academic Research in Education, 2(1), 4250. DOI: 10.17985/ijare.13474 


\section{INTRODUCTION}

English, as an inseparable part of people's academic activities todays, is supposed to be a highlyacknowledged subject to comprehend and learn by EFL learners. Since it has been widely used for various activities by millions of people throughout the world both as their native and a second or foreign language (Ehrlich, 2008; Bolton in Kachru et. al., 2006; Bloomfield, 1973), its importance and purpose should be a main focus on teaching English as a Foreign Language (EFL) learners in an English Language Teaching (ELT) class. It can be said that the purpose of an ELT class is to enhance EFL learners in mastering the four skills of English (Listening, Speaking, Reading, and Writing) including Vocabulary, Grammar, and Pronunciation as parts of real communication in English (Halliday, 1978; Savignon, 2002; Canale and Swain, 1980; Canale, 1983). In achieving the purpose, beliefs about language learning (Horwitz, 2007) has become an important part of English variable that shows whether or not EFL learners are capable, motivated, or talented in learning English.

As EFL contexts are increasing over time throughout the worlds, a lot of studies are conducted in ELT for various focuses such as relationship between metacognitive strategies and beliefs (Wenden, 1999), learning beliefs and learning anxiety (Oh, 1996), learning beliefs and learning autonomy (Carter, 1999), beliefs and learning strategies (Yang, 1992), beliefs among non-native English learners (Tumposky, 1991), beliefs and etnicity (Siebert, 2003), beliefs and instruction (Kuntz, 1999), beliefs among native and nonnative learners (Horwitz, 1983, 1988).

In Indonesia belief about English as a foreign language has always been a focus of development and studies since English, in Indonesia, is now a foreign language. Beliefs about foreign language is considered as a predictor in determining prospective EFL teachers' beliefs about English as a foreign language. The beliefs consists of foreign language aptitude, the difficulty of language learning, the nature of language learning, learning and communication strategies, and motivation and expectation (Horwitz, 1988).

Even though there area studies on ELT in Indonesia, there has been less study focusing on prospective EFL teachers' beliefs about language learning and their relationship to gender. The problem of this study is formulated in the following questions: 1) What beliefs do prospective EFL teachers in Indonesia have about English learning as a foreign language? and 2) What are gender differences on the beliefs about English learning as a foreign language in Indonesia?

The term 'beliefs' is not a strange thing. Beliefs can be associated with who we are and what we are doing with our life. Everyone has beliefs as their identities or the way they act towards various daily routines such as learning English. Experts define beliefs in many ways and views. One definition is that "beliefs cannot be separated from our identities, action, and social experiences" (Barcelos, 2004). Identities, action, and daily experiences reflect what one believes in, does, and decides. EFL learners are reflected by what they believe to do and act when they learn English. In the same idea, Victori \& Lockhart (1995:52) states that "learners, too, bring to their learning their own beliefs, goals, attitudes and decisions, which in turn influence how they approach their learning".

Beliefs determine attitudes of EFL learners. Each learner has their own beliefs in order to behave or show their behavior. McDonough (1995:9) states:"..... what we believe we are doing, what we pay attention to, what we think is important, how we choose to behave, how we prefer to solve problems, form the basis for our personal decisions as to how to proceed". EFL learners has ideas on what they have to do when they are learning English. Each of them may perform differently from different learners depending on their learning styles and strategies which they believe.

Learning styles and strategies can be determined by the beliefs they have in their minds. That is to say that the more positive one's beliefs are, the better learners they will be in learning English. Other experts believe that beliefs can be changed by systematic instruction (Wenden, 1987), but the others believe that they cannot be changed (Peacock, 2001). Such ideas are still questionable and need more studies to 
Mudra, Heri.

prove what have caused the beliefs to change or not to change. Importantly, beliefs about language learning can be helpful for EFL learners who are interested in learning English as a foreign language.

Researchers identify beliefs about language learning (BALL) in various ways. Basically, Beliefs about language learning determines ideas or opinions that learners believe in learning English. Wenden (1987) categorized learner beliefs into three components, namely the use of the language, the learning of the language, and the importance of personal factors. Beliefs about language learning (BALL) consist of five components (Horwitz, 1983, 1988), as follows: foreign language aptitude, difficulty of language learning, nature of language learning, learning and communication strategies, and motivations and expectations. What Wenden and Horwitz have categorized does not sharply show a difference. Wenden's idea is concerned with persons that learn English. Horwitz has complete components of BALL and focuses on person as EFL learners.

\section{Purpose of the study}

The purposes of this research are twofolds. The first purpose is to describe beliefs about English as a foreign language employed by prospective EFL teachers at State Islamic college of Kerinci, Indonesia. The second purpose is to find out gender differences among male and female prospective teachers towards beliefs about language learning. The result of this study is expected to be helpful for prospective EFL teachers to enhance their motivation and strategies in English learning. It is also useful for in-service teachers in finding out ways of teaching English and increasing EFL learners` English knowledge through various strategies.

\section{METHOD}

\section{Participants}

The participants of this research were 100 students of Islamic State College of Kerinci (STAIN Kerinci, Indonesia). Of these, 54 were female students (54\%) and 46 were male students (46\%). The students consisted of different levels, namely freshmen year, sophomores year, juniors year, and seniors year. At the time of data collection, the students were taking English as a Foreign Language (EFL) course.

\section{Instrument}

The instrument employed in this survey was the 34 items "Beliefs about Language Learning Inventory" (BALLI) designed by Horwitz (1987). The 34-items BALLI employs 5-point Likert-scale ranging from "strongly agree" to "strongly disagree" answer choices.

The 34-statements BALLI consist of five relevant areas, as follows:

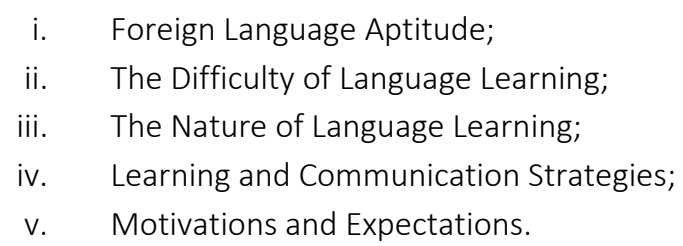

There are some minor changes made in the questionnaire. The item no. 6 "people at my country...." was changed to "Indonesians...." The item no. 20 "people in my country..." was changed to "people in Indonesia". The item no. 26 ".... with cassettes or tapes" was changed to ".... with CDs or DVDs".

The questionnaires consisting of 34-statements BALLI (Horwitz, 1987) were given to 100 students at the beginning of semester in February 2015. The students were asked to fill in the questionnaires based on the time provided by the lecturer and expected for not consulting any information or answer from other 
students. They were asked to work alone in finding out their own beliefs about language learning. They returned the questionnaires back to the lecturer after completed. The data were confidential that the lecturer directly controlled them filling in the forms. In analyzing the data collected, the Statistical Package for Social Science (SPPSS version 16) was employed. Frequencies, means scores, and percentages were used to analyze single items. In order to determine whether there was a significant effect of BALLI on gender, Wilcoxon-Mann-Whitney t-test was used. Such statistical test was used because the data were not normal.

\section{RESULTS}

Based on the objectives of the study, this paper will discuss the beliefs about English as a foreign language and gender differences among prospective EFL teachers. Both objectives will be discussed simultaneously through the tables of five BALLs areas.

The table 1 below shows beliefs and gender (male and female students) differences on foreign language attitude. A great majority (88.9\%, Mean 1.78, Standard Deviation .904) of male students believed that children have more probabilities to master English than adults. This is not followed by female students since only half of them (50\%) believed that statement. Regarding the innate ability people have, both male students (85.2\%) and female students (60.9\%) believed that the innate ability is helpful in learning English. (43.5\%) male students and (40.7\%) female students believed that they can master English easily. They seem to be less confident to give a strong response. Like the preceded item, not half number of male students (42.6\%) believed a foreign language speaker can also learn other things easily, but 50\% female students believed it is true. (41.3\%) male students agreed people who are good at math and science are not good at learning English. However (64.8\%) female students disagreed the statement. They believed that people who are good at math and science learn English easily.

A vast majority of male students (53.7\%) is not sure they have language ability. However, almost half a number of female students (47.8\%) believed that they are able to learn English well. Another disagreement is shown by male students (37\%) who did not believe that women are better than them in learning English. Fortunately, (50\%) female students agreed that they are better than men in learning English. Male students (54.4\%) agreed that those who master some languages are smarter. However, (74.1\%, Mean 2.61, Standard Deviation 1.256) female students showed more agreement than male. (47.8\%) male students believed that all people can learn English, but (64.8\%) female students agreed that everyone can learn English. Wilcoxon-Mann-Whitney test showed no significant differences between male and female students except for item 1 (Mann-Whitney $U=721.000, p=.000$ ) in which mean ranking of male students was higher (61.83) compared to female students (40.85). It proved that male students are likely to believe that children are easier to learn English than adult compared to what female students have responded.

Table 1

Foreign Language Attitude

\begin{tabular}{|c|c|c|c|c|c|c|c|c|}
\hline Item & Gender & 1 & 2 & 3 & 4 & 5 & $\mathrm{M}$ & SD \\
\hline \multirow{2}{*}{$\begin{array}{l}\text { 1. It is easier for children than adults to } \\
\text { learn a foreign language }\end{array}$} & Male & $42.6^{*}$ & 46.3 & 3.7 & 5.6 & 1.9 & 1.78 & .904 \\
\hline & Female & 19.6 & 30.4 & 26.1 & 15.2 & 8.7 & 2.63 & 1.218 \\
\hline \multirow{2}{*}{$\begin{array}{l}\text { 2. Some people are born with a special } \\
\text { ability which helps them to learn a } \\
\text { foreign language }\end{array}$} & Male & 11.1 & 74.1 & 7.4 & 5.6 & 1.9 & 2.13 & .754 \\
\hline & Female & 17.4 & 43.5 & 8.7 & 21.7 & 8.7 & 2.61 & 1.256 \\
\hline \multirow{2}{*}{$\begin{array}{l}\text { 6. Indonesians are good at learning } \\
\text { foreign languages }\end{array}$} & Male & 8.7 & 34.8 & 23.9 & 21.7 & 10.9 & 2.70 & .964 \\
\hline & Female & 11.1 & 29.6 & 38.9 & 18.5 & 1.9 & 2.91 & 1.170 \\
\hline \multirow{2}{*}{$\begin{array}{l}\text { 10. It is easier for someone who already } \\
\text { speaks a foreign language to learn } \\
\text { another one }\end{array}$} & Male & 5.6 & 37 & 29.6 & 20.4 & 7.4 & 2.78 & 1.047 \\
\hline & Female & 15.2 & 34.8 & 21.7 & 28.3 & 0 & 2.63 & 1.062 \\
\hline
\end{tabular}




\begin{tabular}{|c|c|c|c|c|c|c|c|c|}
\hline \multirow{2}{*}{$\begin{array}{l}\text { 11. People who are good at math and } \\
\text { science are not good at learning a foreign } \\
\text { language }\end{array}$} & Male & 17.4 & 23.9 & 21.7 & 28.3 & 8.7 & 3.31 & 1.146 \\
\hline & Female & 9.3 & 11.1 & 33.3 & 31.5 & 14.8 & 2.87 & 1.258 \\
\hline \multirow{2}{*}{$\begin{array}{l}\text { 16. I have a special ability to learn } \\
\text { foreign languages }\end{array}$} & Male & 5.6 & 18.5 & 53.7 & 18.5 & 3.7 & 2.96 & .868 \\
\hline & Female & 4.3 & 43.5 & 26.1 & 15.2 & 10.9 & 2.85 & 1.095 \\
\hline \multirow{2}{*}{$\begin{array}{l}\text { 19. Women are better than men at } \\
\text { learning foreign languages }\end{array}$} & Male & 7.4 & 29.6 & 37 & 20.4 & 5.6 & 2.87 & 1.010 \\
\hline & Female & 15.2 & 34.8 & 10.9 & 26.1 & 26.1 & 2.87 & 1.327 \\
\hline \multirow{2}{*}{$\begin{array}{l}\text { 30. People who speak more than one } \\
\text { language well are very intelligent }\end{array}$} & Male & 19.6 & 34.8 & 21.7 & 13.0 & 10.9 & 2.09 & .853 \\
\hline & Female & 24.1 & 50 & 18.5 & 7.4 & 0 & 2.61 & 1.256 \\
\hline \multirow{2}{*}{$\begin{array}{l}\text { 33. Everyone can learn to speak a } \\
\text { foreign language }\end{array}$} & Male & 13 & 34.8 & 23.9 & 19.6 & 8.7 & 2.46 & 1.111 \\
\hline & Female & 14.8 & 50 & 16.7 & 11.1 & 7.4 & 2.76 & 1.177 \\
\hline
\end{tabular}

As shown in table 2 below, a majority of both male students (76.1\%, Mean: 2.30, Standard Deviation: .816) and female students (74.1\%, Mean:2.37, Standard Deviation: 1.162) believed that English is one of the languages that are easier to learn. Only (17.4\%) male students and (13\%) female students did not believe in that statement. Related to English language, (39.2\%) male students thought that English is a difficult language; (30.4\%) male students thought that it is an easy language. However, (55.5\%) female students felt that English is difficult for them to learn; (14.9\%) female students felt is an easy language. Male students (47.9\%) believed that they will be able to learn English really well. However (77\%) female students were sure they will know English well. Only (43.5\%) male students were sure that English can be learnt less than a year. However, (57.4\%) female students were pretty sure they can learn English less than a year.

(63.1\%) male and (55.5\%) female students thought that they can speak English verbally, but feel hard to understand it. (56.1\%) male students agreed that reading and writing skills in English are easier than understanding it. Less than half a number of female students (40.8\%) agreed that English reading and writing are easier.

Table 2

\section{Difficulty of Language Learning}

\begin{tabular}{|c|c|c|c|c|c|c|c|c|}
\hline Item & Gender & 1 & 2 & 3 & 4 & 5 & $\mathrm{M}$ & SD \\
\hline $\begin{array}{l}\text { 3. Some languages are easier to learn than } \\
\text { others }\end{array}$ & $\begin{array}{l}\text { Male } \\
\text { Female }\end{array}$ & $\begin{array}{c}15.2^{*} \\
9.3\end{array}$ & $\begin{array}{l}60.9 \\
64.8\end{array}$ & $\begin{array}{l}6.5 \\
13\end{array}$ & $\begin{array}{l}6.5 \\
13\end{array}$ & $\begin{array}{c}10.9 \\
0\end{array}$ & $\begin{array}{l}2.30 \\
2.37\end{array}$ & $\begin{array}{l}.816 \\
1.162\end{array}$ \\
\hline $\begin{array}{l}\text { 4. English is: (a) a very difficult language; (b) a } \\
\text { difficult language; (c) a language of medium } \\
\text { difficulty; (d) an easy language; (e) a very easy } \\
\text { language }\end{array}$ & $\begin{array}{l}\text { Male } \\
\text { Female }\end{array}$ & $\begin{array}{l}10.9 \\
11.1\end{array}$ & $\begin{array}{l}28.3 \\
44.4\end{array}$ & $\begin{array}{l}30.4 \\
29.6\end{array}$ & $\begin{array}{c}17.4 \\
9.3\end{array}$ & $\begin{array}{l}13 \\
5.6\end{array}$ & $\begin{array}{l}2.54 \\
2.93\end{array}$ & $\begin{array}{l}1.004 \\
1.200\end{array}$ \\
\hline $\begin{array}{l}\text { 5. I believe that I will ultimately learn to speak } \\
\text { English very well }\end{array}$ & $\begin{array}{l}\text { Male } \\
\text { Female }\end{array}$ & $\begin{array}{l}19.6 \\
16.7\end{array}$ & $\begin{array}{l}28.3 \\
59.3\end{array}$ & $\begin{array}{c}17.4 \\
13\end{array}$ & $\begin{array}{c}28.3 \\
7.4\end{array}$ & $\begin{array}{l}6.5 \\
3.7\end{array}$ & $\begin{array}{l}2.74 \\
2.22\end{array}$ & $\begin{array}{c}1.255 \\
.945 \\
\end{array}$ \\
\hline 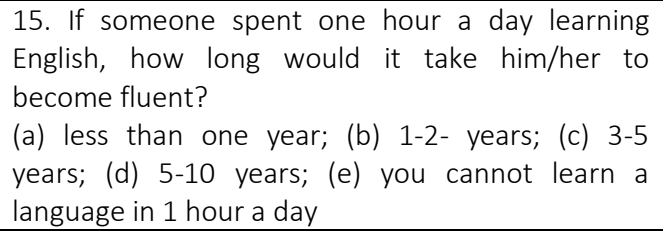 & $\begin{array}{l}\text { Male } \\
\text { Female }\end{array}$ & $\begin{array}{l}15.2 \\
11.1\end{array}$ & $\begin{array}{l}28.3 \\
46.3\end{array}$ & $\begin{array}{l}28.3 \\
20.4\end{array}$ & $\begin{array}{c}13 \\
14.8\end{array}$ & $\begin{array}{l}15.2 \\
7.4\end{array}$ & $\begin{array}{l}2.61 \\
2.85\end{array}$ & $\begin{array}{l}.945 \\
1.255\end{array}$ \\
\hline $\begin{array}{l}\text { 25. It is easier to speak than understand the } \\
\text { English }\end{array}$ & $\begin{array}{l}\text { Male } \\
\text { Female }\end{array}$ & $\begin{array}{l}17.4 \\
14.8\end{array}$ & $\begin{array}{l}45.7 \\
40.7\end{array}$ & $\begin{array}{l}15.2 \\
31.5\end{array}$ & $\begin{array}{c}15.2 \\
13\end{array}$ & $\begin{array}{c}6.5 \\
0 \\
\end{array}$ & $\begin{array}{l}2.43 \\
2.48\end{array}$ & $\begin{array}{l}.903 \\
1.150 \\
\end{array}$ \\
\hline $\begin{array}{l}\text { 34. It is easier to read and write English than to } \\
\text { understand it }\end{array}$ & $\begin{array}{l}\text { Male } \\
\text { Female }\end{array}$ & $\begin{array}{c}17.4 \\
13\end{array}$ & $\begin{array}{l}39.1 \\
27.8\end{array}$ & $\begin{array}{l}23.9 \\
33.3\end{array}$ & $\begin{array}{c}13 \\
22.2\end{array}$ & $\begin{array}{l}6.5 \\
3.7\end{array}$ & $\begin{array}{l}2.76 \\
2.62\end{array}$ & $\begin{array}{l}1.063 \\
1.130\end{array}$ \\
\hline
\end{tabular}


The table 3 below shows that (45.7\%) male students disagreed and that learning native cultures are more important before learning how to speak the language. However, (57.4\%) female students disagreed that the cultures are learnt before learning its speaking skill. (56.5\%) male students agreed that English should be learnt in an English-speaking country. However, only (31.5\%) female students agreed that native country of English is a better place to learn English.

(50\%) male student believed that English vocabulary is important to learn. However, (72.3\%) female students believed that learning vocabulary is important. (60.9\%) male students believed that grammar is important in English skill. However, a majority of (74.1\%) female students agreed that English grammar is important to learn. A majority of (71.7\%) male and (72.3\%) female students agreed that learning English is different than learning other courses.

Table 3

The Nature of Language Learning

\begin{tabular}{|c|c|c|c|c|c|c|c|c|}
\hline Item & Gender & 1 & 2 & 3 & 4 & 5 & $\mathrm{M}$ & SD \\
\hline \multirow{2}{*}{$\begin{array}{l}\text { 8. It is necessary to know about English-speaking } \\
\text { cultures in order to learn to speak English }\end{array}$} & Male & $8.7^{*}$ & 32.6 & 13 & 28.3 & 17.4 & 3.13 & 1.293 \\
\hline & Female & 5.6 & 13 & 24.1 & 40.7 & 16.7 & 3.5 & 1.095 \\
\hline $\begin{array}{l}\text { 12. It is best to learn English in an English-speaking } \\
\text { country }\end{array}$ & Female & 13 & 18.5 & 31.5 & 33.3 & 3.7 & 2.96 & 1.098 \\
\hline $\begin{array}{l}\text { 17. The important part of learning English is } \\
\text { learning vocabulary words }\end{array}$ & Male & 10.9 & 39.1 & 34.8 & 10.9 & 4.3 & 2.59 & .979 \\
\hline $\begin{array}{l}\text { 23. The most important part of learning English is } \\
\text { the grammar }\end{array}$ & Female & 27.8 & 46.3 & 16.7 & 9.3 & 0 & 2.07 & .908 \\
\hline \multirow{2}{*}{$\begin{array}{l}\text { 27. Learning a foreign language is different than } \\
\text { learning other academic subjects. }\end{array}$} & Male & 15.2 & 56.5 & 15.2 & 8.7 & 4.3 & 2.3 & .986 \\
\hline & Female & 13 & 59.3 & 16.7 & 5.6 & 5.6 & 2.31 & .968 \\
\hline $\begin{array}{l}\text { 1=Strongly Agree }(\mathrm{SA}) ; 2=\text { Agree }(\mathrm{A}) ; 3=\text { Neutral }(\mathrm{N}) ; 4=\mathrm{D} \\
\text { M=Mean; SD=Standard Deviation } \\
\text { *Percentages of responses }(\%)\end{array}$ & agree (D); & $5=$ Stro & gly Di & agree ( & D) & & & \\
\hline
\end{tabular}

Table 4 below shows that (56.5\%) male students thought that speaking English with great pronunciation is important. However, a majority (79.6\%) female students believed that it is important to speak English with excellent pronunciation. Less than a half of male students (43.5\%) and (42.6\%) female students agreed that it is a must to use correct verbal English. Less than a half of male students (41.3\%) believed that they love using English with native English speakers. However, more than a half of female students (55.5\%) agreed that they do enjoy practicing English with native English speakers.

Less than a half of male students (43.5\%) believed that it is okay for them to guess if they do not know any word. However, half a number of female students (50\%) believed that guessing strategy is okay to be used in English. (50\%) of male students agreed that more repetition and practice are important. A majority (79.6\%) of female students felt that it is important to repeat and practice in English. (56.6\%) male students felt timid to use English to the others. However, (35.2\%) female students felt timid to practice using English to other students. (43.5\%) male students believed that being permitted in making errors will make them hard to speak well later on; however, (41.3\%) male students disagreed that statement. A majority of (63\%) female students felt that it is a problem for learners to speak correctly if they are permitted to make errors when learning English for the first time. A majority (76.1\%) of male students and (70.4\%) of female students thought that it is important to learn English by using CDs or DVDs. 
Learning and Communication Strategies

\begin{tabular}{|c|c|c|c|c|c|c|c|c|}
\hline Item & Gender & 1 & 2 & 3 & 4 & 5 & $\mathrm{M}$ & SD \\
\hline \multirow{2}{*}{$\begin{array}{l}\text { 7. It is important to speak English with excellent } \\
\text { pronunciation }\end{array}$} & Male & $21.7^{*}$ & 34.8 & 10.9 & 23.9 & 8.7 & 2.63 & 1.306 \\
\hline & Female & 29.6 & 50 & 7.4 & 11.1 & 1.9 & 2.06 & .998 \\
\hline \multirow{2}{*}{$\begin{array}{l}\text { 9. You shouldn`t say anything in English until you } \\
\text { can say it correctly }\end{array}$} & Male & 10.9 & 32.6 & 13 & 23.9 & 19.6 & 3.09 & 1.347 \\
\hline & Female & 5.6 & 37 & 13 & 40.7 & 3.7 & 3 & 1.082 \\
\hline \multirow{2}{*}{$\begin{array}{l}\text { 13. I enjoy practicing English with native speakers } \\
\text { of English }\end{array}$} & Male & 13 & 28.3 & 30.4 & 17.4 & 10.9 & 2.85 & 1.192 \\
\hline & Female & 11.1 & 44.4 & 31.5 & 13 & 0 & 2.46 & .862 \\
\hline \multirow{2}{*}{$\begin{array}{l}\text { 14. It is okay to guess if you don't know a word in } \\
\text { English }\end{array}$} & Male & 6.5 & 37 & 23.9 & 19.6 & 13 & 2.96 & 1.173 \\
\hline & Female & 5.6 & 44.4 & 29.6 & 18.5 & 1.9 & 2.67 & .911 \\
\hline \multirow[t]{2}{*}{ 18. It is important to repeat and practice a lot } & Male & 30.4 & 19.6 & 15.2 & 21.7 & 13 & 2.67 & 1.446 \\
\hline & Female & 40.7 & 38.9 & 13 & 3.7 & 3.7 & 1.91 & 1.014 \\
\hline \multirow[t]{2}{*}{ 21. I feel timid speaking English with other people } & Male & 10.9 & 45.7 & 21.7 & 17.4 & 4.3 & 2.59 & 1.045 \\
\hline & Female & 3.7 & 31.5 & 25.9 & 33.3 & 5.6 & 3.06 & 1.017 \\
\hline \multirow{2}{*}{$\begin{array}{l}\text { 22. If beginning students are permitted to make } \\
\text { errors in English, it will be difficult for them to } \\
\text { speak correctly later on }\end{array}$} & Male & 17.4 & 26.1 & 15.2 & 32.6 & 8.7 & 2.89 & 1.286 \\
\hline & Female & 9.3 & 53.7 & 18.5 & 13 & 5.6 & 2.52 & 1.023 \\
\hline \multirow[t]{2}{*}{ 26. It is important to practice with CDs or DVDs } & Male & 28.3 & 47.8 & 13 & 8.7 & 2.2 & 2.09 & .985 \\
\hline & Female & 14.8 & 55.6 & 24.1 & 5.6 & 0 & 2.43 & .903 \\
\hline
\end{tabular}

1=Strongly Agree (SA); 2=Agree (A); 3=Neutral (N); 4=Disagree (D); 5=Strongly Disagree (SD)

$\mathrm{M}=$ Mean; $\mathrm{SD}=\mathrm{Stan}$ dard Deviation

*Percentages of responses (\%)

As shown in table 5 below, (63\%) male students thought that it is important for Indonesians to speak English. However, less than a half of female students (48.1\%) felt that speaking English for Indonesians is important. (60.9\%) male students learn English in order to know English speakers well. However, a majority of female students (75.9\%) thought that by learning English, they will know native-English speakers well.

A majority of male students (69.6\%) felt that they can get a better job with English skill. More than a half of female students (55.6\%) thought that a better job can be achieved by learning English. A majority of male students (71.6\%) and (81.5\%) of female students would like to learn English very well. (63.1\%) male students and (64.9\%) female students would like to have friends who are native speakers of English.

Table 5

Motivations and Expectations

\begin{tabular}{llccccccc}
\hline \multicolumn{1}{c}{ Item } & Gender & 1 & 2 & 3 & 4 & 5 & M & SD \\
\hline 20. People in Indonesia feel that it is important to & Male & $21.7^{*}$ & 41.3 & 21.7 & 10.9 & 4.3 & 2.35 & 1.079 \\
speak English & Female & 11.1 & 37 & 29.6 & 20.4 & 1.9 & 2.65 & .994 \\
\hline 24. I would like to learn English so that I can get to & Male & 17.4 & 43.5 & 15.2 & 13 & 10.9 & 2.57 & 1.241 \\
know native speakers of English better & Female & 22.2 & 53.7 & 11.1 & 11.1 & 1.9 & 2.17 & .966 \\
\hline 29. If I learn English very well, I will have better & Male & 19.6 & 50 & 15.2 & 13 & 2.2 & 2.28 & 1.004 \\
opportunities for a good job & Female & 13 & 42.6 & 31.5 & 13 & 0 & 2.44 & .883 \\
\hline 31. I want to learn to speak English very well & Male & 30.4 & 45.7 & 8.7 & 10.9 & 4.3 & 2.13 & 1.108 \\
& Female & 29.6 & 51.9 & 14.8 & 3.7 & 0 & 1.93 & .773 \\
\hline 32. I would like to have friends who are native & Male & 19.6 & 43.5 & 8.7 & 23.9 & 4.3 & 2.50 & 1.188 \\
speakers of English & Female & 13 & 51.9 & 22.2 & 13 & 0 & 2.35 & .872 \\
\hline 1=Strongly Agree (SA); 2=Agree (A); 3=Neutral (N); 4=Disagree (D); 5=Strongly Disagree (SD) & & & \\
M=Mean; SD=Standard Deviation & & & & & & &
\end{tabular}

\section{CONCLUSION}

This research employed Beliefs about Language Learning Inventory (BALLI) which was firstly found by 
Horwitz (1987). The purpose of this research was to explore whether there is a statistically gender difference between male and female students' beliefs about English as a foreign language. Overall, male and female students share statistical similarities in BALLs. However, there are some items that show statistically gender differences between both male and female students. The first significant difference is on the item that states whether or not students who are good at maths could not understand English well. More female students agreed on this, but fewer male students agreed this statement. Another item that shows significant difference between the gender is about whether or not they can ultimately understand English very well. More female students did believe in this statement, but a few number of male students did not believe in it.

The statistically difference in gender is an indicator of various views from both male and female students. What they feel or state might reflect what they have experienced or are doing. Another possibility of this differences is that each student has different ability and skill. Moreover, each of them views English as a foreign language in a variety of ways.

\section{References}

Barcelos, A. 2000. Understanding teachers' and students' language learning beliefs in experience: A Deweyan approach (John Dewey). Unpublished doctoral dissertation. The University of Alabama, Tuscaloosa.

Bolton, Kinsley. 2006. World Englishes Today. In Kachru, Braj B., Yamuna Kachru, and Cecil L. Nelson (eds). The Handbook of World Englishes. New York: Blackwell Publisher

Bloomfield, Leonard. 1973. Language. London: Compton Printing Ltd.

Canale, M. 1983. From communicative competence to communicative pedagogy. In J. C. Richards and R. W. Schmidt, eds., Language and Communication. London: Longman.

Canale, M., and M. Swain. 1980. Theoretical bases of communicative approaches to second language teaching and testing. Applied Linguistics 1, 1-47.

Carter, B.A. 1999. Begin with beliefs: exploring the relationship between beliefs and learner autonomy among advanced students. Texas Papers in Foreign Language Education, 4(1), 1-20.

Ehrlich, S. 2008. Gender as social practice. Implications for second language acquisition. Studies in Second Language Acquisition, 19, 421-446.

Halliday, M. A. K. 1978. Language as Social Semiotic: The Social Interpretation of Language and Meaning. Baltimore: University Park Press.

Horwitz, E. 1987. The beliefs about language learning of beginning university foreign language students. Modern Language Journal, 72, 283-294.

Kuntz, P. 1999. Secondary Students' Beliefs about Language Learning. (ERIC Document Reproduction Service, No. ED427514).

McDonough, S. 1995. Strategy and Skill in Learning a Foreign Language. London: Edward Arnold.

Peacock, M. 2001. Preservice ESL teachers' beliefs about second language learning: A longitudinal study. System 29(2), 177-195.

Siebert, L. 2003. Student and teacher beliefs about language learning. The ORTESOL Journal, 21, 7-39. 
Mudra, Heri.

Tumposky, N.R. 1991. Student beliefs about language learning: A crosscultural study. Carleton Papers in Applied Language Studies, 8, 50-65.

Victori, M. \& Lockhart, W. 1995. Enhancing Metacognition in self-directed learning. self-directed learning. System 23, 2, pp. 223-234.

Wenden, A. 1987. How to be a successful language learner: Insights and Prescriptions from L2 learners. In A. Wenden and J. Rubin (Eds.), Learner strategies in language learning (pp.103-117). London: Prentice Hall.

Wenden, A. 1999. An introduction to metacognitive knowledge and beliefs about language learning: Beyond the basics. System, 27, 435-441.

Yang, N.D. 1992. Second language learners' beliefs about language learning and their use of learning strategies: A study of college students of English in Taiwan. Unpublished doctoral dissertation. The University of Texas, Austin. 